\title{
Burden of Disease from Rising Coal-Fired Power Plant Emissions in Southeast Asia
}

\author{
Shannon N. Koplitz, ${ }^{* \dagger \odot}$ Daniel J. Jacob, ${ }^{\ddagger}$ Melissa P. Sulprizio, ${ }^{\ddagger}$ Lauri Myllyvirta, ${ }^{\S}$ and Colleen Reid" \\ ${ }^{\dagger}$ Department of Earth and Planetary Sciences, Harvard University, Cambridge, Massachusetts 02138 United States \\ "John A. Paulson School of Engineering and Applied Sciences, Harvard University, Cambridge, Massachusetts 02138 United States \\ ${ }^{\S}$ Greenpeace International, $1066 \mathrm{AZ}$ Amsterdam, The Netherlands \\ "Department of Geography, University of Colorado, Boulder, Colorado 80309 United States
}

\author{
Supporting Information
}

\begin{abstract}
Southeast Asia has a very high population density and is on a fast track to economic development, with most of the growth in electricity demand currently projected to be met by coal. From a detailed analysis of coal-fired power plants presently planned or under construction in Southeast Asia, we project in a business-as-usual scenario that emissions from coal in the region will triple to $2.6 \mathrm{Tg} \mathrm{a}^{-1} \mathrm{SO}_{2}$ and $2.6 \mathrm{Tg} \mathrm{a}^{-1} \mathrm{NO}_{x}$ by 2030 , with the largest increases occurring in Indonesia and Vietnam. Simulations with the GEOSChem chemical transport model show large resulting increases in surface air pollution, up to $11 \mu \mathrm{g} \mathrm{m}^{-3}$ for annual mean fine particulate matter $\left(\mathrm{PM}_{2.5}\right)$ in northern Vietnam and up to 15 ppb for seasonal maximum $1 \mathrm{~h}$ ozone in Indonesia. We estimate 19880 (11 400-28 400) excess deaths per year from Southeast Asian coal emissions at present, increasing to 69660 (40 080-126 710) by 2030. 9000 of these excess deaths in 2030 are in China. As Chinese emissions from coal decline in coming decades, transboundary pollution influence from rising coal emissions in Southeast Asia may become an increasing issue.
\end{abstract}

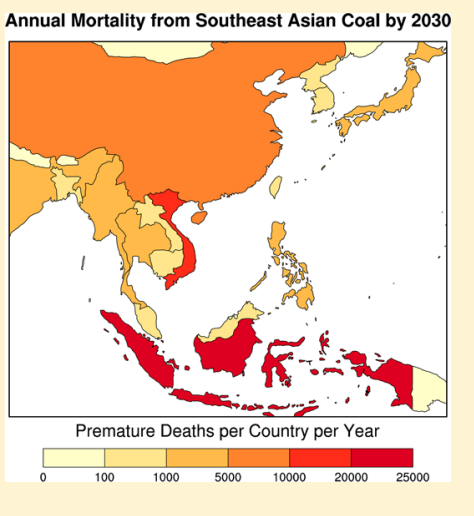

\section{INTRODUCTION}

Coal emissions have been decreasing in the U.S. and Europe for the past two decades due to concern over public health and now increasingly over climate change. In contrast, coal emissions in much of Asia have been increasing rapidly. ${ }^{1,2}$ Air quality impacts of coal use in China and India have received considerable attention. ${ }^{3-6}$ Far less attention has been given to the growing use of coal in Southeast Asia including Indonesia, Vietnam, Thailand, and neighboring countries. Southeast Asia is one of the fastest developing regions in the world; electricity demand in 2035 is projected to increase by $83 \%$ from 2011 levels, more than twice the global average. ${ }^{7}$ Accompanying this economic development is population growth. Indonesia alone is projected to increase its population by 67 million people (28\%) between 2010 and 2035. Population migration from rural areas to cities, or "urbanization", also increases population densities in polluted areas and heightens demand for grid-based electricity produced by power plants; urbanization rates in Southeast Asia are some of the highest globally, and are projected to increase significantly by $2030 .^{9}$ This growing demand for energy is presently expected to be met by coal because of its low cost and domestic abundance. ${ }^{10}$ We show here that the public health consequences would be severe.

Coal combustion emits sulfur dioxide $\left(\mathrm{SO}_{2}\right)$ and nitrogen oxides $\left(\mathrm{NO}_{x}\right)$, leading to formation of fine particulate matter $\left(\mathrm{PM}_{2.5}\right.$, particles less than $2.5 \mu \mathrm{m}$ in diameter) and ozone. $\mathrm{PM}_{2.5}$ increases the risk of premature mortality from respiratory and cardiovascular disease. It is the most harmful air pollutant to human health worldwide. ${ }^{11}$ Surface ozone is also a major concern for public health and ecosystems. ${ }^{12,13}$ Emissions of $\mathrm{SO}_{2}$ and $\mathrm{NO}_{x}$ can vary widely by coal plant depending on the grade of coal combusted, the type of boiler used, and the emission controls in place. ${ }^{14,15}$

Here we estimate the burden of air pollution disease due to current (2011) and projected (2030) coal use in Southeast Asia and other East Asian countries outside of China and India. Our 2030 projection is for a "coal future" scenario including all plants currently in construction or in the planning stages. The resulting $\mathrm{PM}_{2.5}$ and ozone concentrations are computed with a high-resolution version of the GEOS-Chem global 3-D chemical transport model, and the resulting premature mortalities are estimated using approaches from the health impact assessment literature.

\section{MATERIALS AND METHODS}

GEOS-Chem Simulations. We use the GEOS-Chem simulation of aerosol-oxidant chemistry ${ }^{16,17}$ (v9-02; http:// geos-chem.org) driven by 2011 assimilated meteorological data from the Goddard Earth Observation System (GEOS-5) of the NASA Global Modeling and Assimilation Office (GMAO). We use 2011 meteorology for consistency with the updated coal

Received: July 25, 2016

Revised: November 21, 2016

Accepted: December 14, 2016

Published: January 12, 2017 
Table 1. National Inventories of Emissions from Coal-Fired Power Plants $\left(\mathrm{Tg} \mathrm{a}^{-1}\right) .^{a}$

\begin{tabular}{|c|c|c|c|c|c|c|c|c|}
\hline \multirow[b]{2}{*}{ country } & \multicolumn{2}{|c|}{ number of plants } & \multicolumn{2}{|c|}{$\mathrm{SO}_{2}$} & \multicolumn{2}{|c|}{$\mathrm{NO}_{x}$} & \multicolumn{2}{|c|}{$\mathrm{PM}_{2.5}$} \\
\hline & 2011 & 2030 & 2011 & 2030 & 2011 & 2030 & 2011 & 2030 \\
\hline Cambodia & 1 & 6 & $<0.01$ & $<0.01$ & $<0.01$ & $<0.01$ & $<0.01$ & $<0.01$ \\
\hline Indonesia & 147 & 323 & 0.29 & 0.90 & 0.29 & 0.88 & 0.03 & 0.05 \\
\hline Japan & 160 & 172 & 0.10 & 0.12 & 0.10 & 0.12 & $<0.01$ & $<0.01$ \\
\hline Laos & 0 & 3 & $<0.01$ & $<0.01$ & $<0.01$ & $<0.01$ & $<0.01$ & $<0.01$ \\
\hline Malaysia & 18 & 26 & 0.05 & 0.07 & 0.07 & 0.11 & $<0.01$ & $<0.01$ \\
\hline Myanmar & 3 & 16 & 0.01 & 0.30 & $<0.01$ & 0.18 & $<0.01$ & 0.01 \\
\hline Philippines & 30 & 77 & 0.07 & 0.19 & 0.08 & 0.25 & $<0.01$ & 0.01 \\
\hline South Korea & 97 & 123 & 0.06 & 0.10 & 0.08 & 0.12 & $<0.01$ & $<0.01$ \\
\hline Taiwan & 71 & 81 & 0.03 & 0.04 & 0.05 & 0.06 & $<0.01$ & $<0.01$ \\
\hline Thailand & 37 & 48 & 0.14 & 0.20 & 0.11 & 0.15 & 0.01 & 0.01 \\
\hline Vietnam & 38 & 133 & 0.09 & 0.63 & 0.08 & 0.69 & 0.01 & 0.07 \\
\hline total & 602 & 1008 & 0.84 & 2.60 & 0.86 & 2.63 & 0.06 & 0.16 \\
\hline
\end{tabular}

${ }^{a}$ Annual emissions for 2011 and projections for 2030. See SI for individual plant locations and emissions. The 2030 projections are for a business-asusual, coal future scenario including all plants currently planned or under construction, with emission controls based on current national standards and practices. See text for details.

plant emissions data (described below). The GEOS-5 data have $0.5^{\circ} \times 0.666^{\circ}$ native horizontal resolution and 72 vertical levels (14 levels below $2 \mathrm{~km}$ ). The GEOS-Chem simulation is conducted at the native resolution over East Asia and adjacent oceans (11S-55 N, 70-150 E), ${ }^{18,19}$ nested within a global simulation at $2^{\circ} \times 2.5^{\circ}$ resolution that provides dynamic boundary conditions. This East Asian nested version of GEOSChem has been extensively evaluated for China with observations of aerosols ${ }^{19-23}$ and ozone. ${ }^{24-27}$ Evaluations have also been performed for Southeast Asia, ${ }^{28,29}$ but observations are more limited in that region.

Global anthropogenic emissions of $\mathrm{SO}_{2}$ and $\mathrm{NO}_{x}$ are from the Emissions Database for Global Atmospheric Research (EDGAR) v4.2 for 2008, the most recently available year at the time of this analysis (http://edgar.jrc.ec.europa.eu). Coal emissions in East Asian countries outside of China and India are superseded by our own inventories, as described below.

We conduct three 1-year simulations using 2011 meteorology, differing only in their coal emissions for East Asia outside of China and India: (1) 2011 coal emissions, (2) 2030 emissions projected for the coal future scenario, and (3) zero coal emissions. EDGAR provides total emissions from energy generation but does not resolve the contribution of each fuel type. We isolate the coal-related emissions by gridding and subtracting our 2011 emissions from the EDGAR values in each grid square at $1^{\circ} \times 1^{\circ}$ horizontal resolution, resulting in scenario (3). If this subtraction results in a negative no-coal value (i.e., our 2011 emissions exceed the EDGAR value for that grid square), the no-coal value for that grid square is set to zero. We then add in either our 2011 emissions or projected 2030 emissions to create scenarios (1) and (2). Changes in $\mathrm{PM}_{2.5}$ and ozone pollution due to coal emissions are then calculated as the difference between scenarios (1) and (3) for 2011, and (2) and (3) for 2030. We simulate scenarios (1) and (2) for all countries included in Table 1 taken together, as well as for each country individually (i.e., emissions in that country are set to zero). Our analysis here will mostly focus on totals for all countries taken together, but the results for individual countries (called "national simulations"; Supporting Information (SI) Figures S1-S2) are used to separate domestic and transboundary pollution influences. Each simulation was initialized for four months prior to January 2011.
National Coal Emission Inventories. We implement into GEOS-Chem a new plant-specific inventory for 2011 coal emissions of $\mathrm{SO}_{2}, \mathrm{NO}_{x}$, and primary $\mathrm{PM}_{2.5}$ in East Asia outside of China and India. Countries included are Cambodia, Indonesia, Japan, Laos, Malaysia, Myanmar, the Philippines, South Korea, Taiwan, Thailand, and Vietnam (Table 1). Plant location and capacity information are based on the Platts Utility Data Institute (UDI) World Electric Power Plant Database (WEPP). ${ }^{30}$ Plant locations are shown in SI Figure S3. Plantspecific emission estimates and parameter values are available in the SI. Our approach for estimating pollutant emissions at each facility is described below.

The magnitude of emissions from coal plants varies widely for individual facilities depending on (1) the grade of coal combusted (lignite, sub-bituminous, bituminous, or anthracite), (2) the sulfur content of the coal, (3) the type of boiler used to combust the coal, (4) emission control technologies, and (5) the operational profile of the facility defined by the electricity generation capacity, load factor (ratio of the average output to the maximum possible output), and thermal efficiency (amount of electrical energy output per unit of coal heat content consumed). Factors (1)-(4) determine the stack gas concentration at a given facility in units of $\mathrm{mg} \mathrm{Nm}^{-3}$ (the " $\mathrm{N}$ " denotes normalized to dry conditions at 1 atm, 6\% excess oxygen, 25 $\left.{ }^{\circ} \mathrm{C}\right)$. Factor (5) determines the fuel consumption $\mathrm{H}\left[\mathrm{GJ} \mathrm{a}^{-1}\right]$ at facility i:

$$
H_{i}=\frac{\lambda_{i} \gamma_{i}}{\eta_{i}}
$$

where $\lambda\left[\mathrm{GJ} \mathrm{a}^{-1}\right]$ is the electric capacity, $\gamma$ is the fractional load factor, and $\eta$ is the thermal efficiency. Multiplying the fuel consumption by the stack gas concentration of pollutant $\mathrm{j}(\Omega)$ and specific flue gas volume of the fuel used $\sigma\left[\mathrm{Nm}^{3} \mathrm{GJ}^{-1}\right]$ yields annual emission estimates $E_{i, j}\left[\mathrm{Tg} \mathrm{a}^{-1}\right]$ of pollutant $\mathrm{j}$ from facility i:

$$
E_{i, j}=H_{i} \sigma_{i} \Omega_{i, j}
$$

Operational data for $\eta$ and $\gamma$ for most existing plants were obtained from the Carbon Monitoring for Action Database (CARMA; ${ }^{31}$ http://www.carma.org). For individual plants not covered by CARMA, national average values were calculated and applied based on information available for plant size and 
$\mathrm{SO}_{2}$ emissions from coal plants
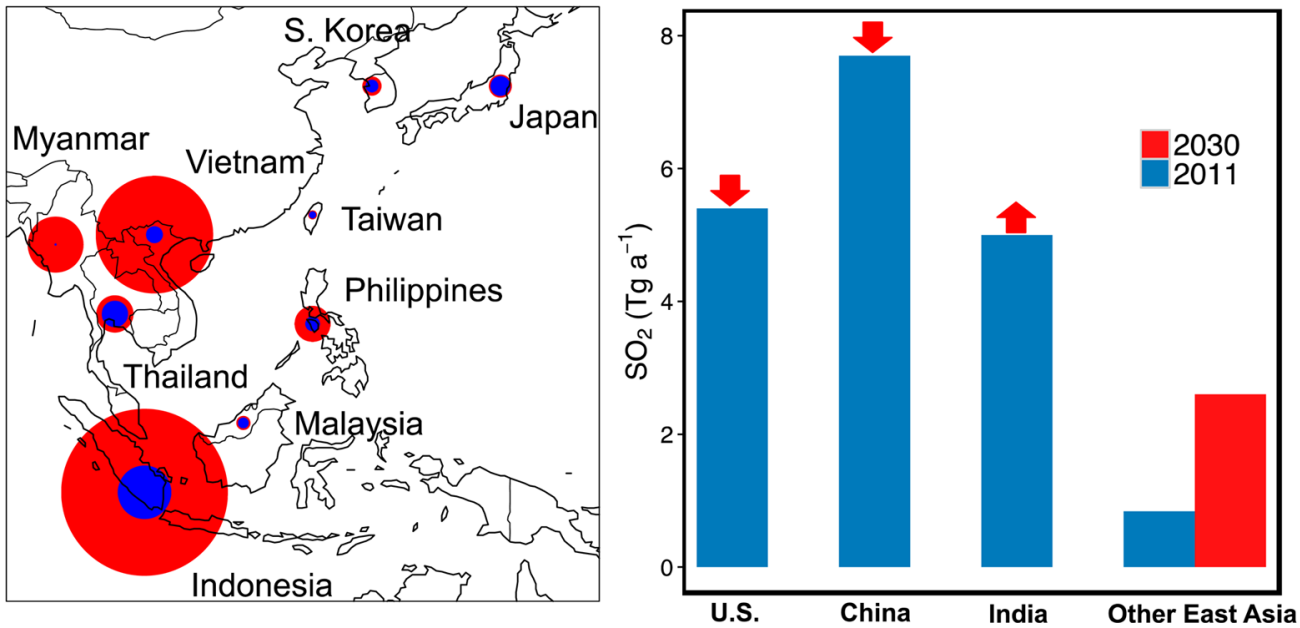

Figure 1. Coal $\mathrm{SO}_{2}$ emissions in 2011 and 2030 for the countries considered in this work (see Table 1). The left panel shows national emissions in 2011 and 2030, where the areas of the circles are proportional to emissions (see SI Figure S3 for plant locations). The right panel compares 2011 and 2030 total regional emissions from countries in this work ("Other East Asia") to 2010 estimates for the U.S. ${ }^{41}$ China, ${ }^{38}$ and India. ${ }^{39}$ The red arrows denote the signs of projected future trends for China, India, and the U.S.

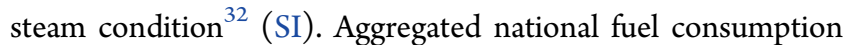
totals were scaled to match the 2011 statistics for total coal consumption in the power sector by country from the International Energy Agency (IEA). Fuel consumption values at individual facilities were then adjusted based on these national scale factors derived from the IEA comparison. Specific flue gas volume estimates of $337.1 \mathrm{Nm}^{3} \mathrm{GJ}^{-1}$ for hard coal (anthracite, bituminous, sub-bituminous) and $360.6 \mathrm{Nm}^{3} \mathrm{GJ}^{-1}$ for lignite were used based on data from the European Environment Agency. ${ }^{33}$ If coal type was not reported, we assumed the specific flue gas volume for hard coal.

Stack gas concentrations $(\Omega)$ used in eq 2 were obtained through three different approaches, in order of preference: a) reported stack gas concentrations for the facility; b) company averages provided by Corporate Social Responsibility (CSR) reports; c) national emission standard based on electric capacity and operational start year of the facility. References are in the SI.

In countries that do not regulate stack emission concentrations of pollutants (Myanmar for all pollutants; Taiwan for $\mathrm{SO}_{2}$ and $\mathrm{NO}_{x}$ ), rather than using eqs 1 and 2, a national average emission rate per $\mathrm{TJ}$ of power generated by coal was derived from the Regional Emission inventory in Asia (REAS v2.1 ${ }^{34}$ ). These emission rates were then combined with the 2011 IEA estimates for total power generation from coal for that country to estimate total national emissions in 2011. The derived national emission totals were then spatially allocated to individual facilities based on capacity.

Primary particulate matter (PM) emissions from power plants are often reported in terms of total PM. To obtain estimates of $\mathrm{PM}_{2.5}$ specifically, $\mathrm{PM}_{2.5}$ fractions were estimated using PM size distributions from the U.S. Environmental Protection Agency AP-42 database ${ }^{35}$ for different control technologies when plant-specific emission control technology information was available. Otherwise we assumed the use of an electrostatic precipitator (ESP) to remove fine primary particles with a $99 \%$ removal efficiency for all plants in countries with any stack emission regulations. If $\mathrm{PM}$ emissions were unregulated or above $500 \mathrm{mg} \mathrm{Nm}{ }^{-3}$ (implying lack of any emission control), we applied the AP-42 particle size distribution associated with uncontrolled combustion.

Emissions from Future Plants. Our 2030 inventory includes the 2011 estimates as well as projected emissions from plants currently listed as under construction or planned based on a comprehensive mapping of new power plant projects from the CoalSwarm database ${ }^{36}$ (see SI for full listing and relevant references). We include the presently operating 2011 plants in our future projections because the average lifetime of a coal plant is $30-40$ years $^{37}$ and most current plants were built after 1990 .

New power plants are assumed to meet current national emission standards for new plants (when more specific information about emissions is not available), and to operate at a load factor of $80 \%$, in line with available data from CARMA for newly operational units in this region. For countries in which 2011 emission rates from existing plants are below national standards, new power plants are assumed to overachieve the standards by the same ratio. In addition, when information about the emission control configuration is reported at a facility planned or under construction, standard performance in the control of emissions (emissions per unit of fuel consumption) is assumed based on the US EPA AP-42 database $^{35}$ values for the technologies in that configuration. Such configuration components include low- $\mathrm{NO}_{x}$ boilers, flue gas desulfurization (FGD), selective catalytic reduction devices, and baghouses (see SI for full list). All new power plants for which information on particulate control technology is not available are still assumed to install an ESP (described above).

In countries with lenient emission standards for new power plants such as Indonesia and Myanmar, these minimum emission control performance assumptions likely lead to conservative emission estimates from new plants and therefore a possible underestimate of future coal pollution and health impacts in these countries. On the other hand, our 2030 estimates represent a "Business As Usual" scenario where we do not account for possible future improvements in the extent or type of emission control technologies.

Coal-fired power plant emissions of $\mathrm{SO}_{2}, \mathrm{NO}_{x}$, and $\mathrm{PM}_{2.5}$ for each country in 2011 and 2030 are listed in Table 1. National 
$\mathrm{SO}_{2}$ emissions for 2011 and 2030 are shown in Figure 1. Total $\mathrm{SO}_{2}$ emissions from coal in 2011 are $0.84 \mathrm{Tg} \mathrm{a}^{-1}$ for the countries in Table 1 , as compared to $7.7 \mathrm{Tg} \mathrm{a}^{-1}$ in China ${ }^{38}$ and $\sim 5 \mathrm{Tg} \mathrm{a}^{-1}$ in India. ${ }^{39}$ Total $\mathrm{NO}_{x}$ emissions are $0.86 \mathrm{Tg} \mathrm{a}^{-1}$ for the countries in Table 1 , compared to $8.3 \mathrm{Tg} \mathrm{a}^{-1}$ in China ${ }^{38}$ and $\sim 2 \mathrm{Tg} \mathrm{a}^{-1}$ in India. ${ }^{40}$ Indonesia is the largest East Asian source in 2011 outside of China and India.

By 2030, our projections indicate that total $\mathrm{SO}_{2}$ and $\mathrm{NO}_{x}$ emissions for the countries in Table 1 will increase by a factor of 3, resulting in emissions of $2.6 \mathrm{Tg} \mathrm{a}^{-1}$ each for $\mathrm{SO}_{2}$ and $\mathrm{NO}_{x}$. Southeast Asia dominates this expansion, with Indonesia and Vietnam together accounting for $67 \%$ of the total increase. Indonesia is planning 176 new coal plants by 2030, 75 of which are already under construction, and it has relatively lax emission standards (SI). Myanmar shows the highest relative increase in emissions by 2030 , becoming the third largest emitter after contributing almost no emissions in the present day.

Table 1 shows almost no increase in emissions for Japan between 2011 and 2030. However, 16 GW of additional coalfired capacity has been proposed for Japan since our emission calculations were completed (Kiko Network; http://sekitan.jp/ plant-map/en/v2/table_en). This is more than twice the 6.2 GW of new capacity we assume for Japan in our analysis. This newly announced capacity will likely result in higher emissions by 2030 than is represented in our results. Conversely, the presently operating fleet of Japanese plants is significantly older than for the other countries we consider here. $26 \%$ of Japanese plants operating at the end of 2015 will have exceeded 40 years of operation by 2030 (compared to the regional average of $8 \%){ }^{42} \mathrm{Up}$ to $11 \mathrm{GW}$ of Japanese fleet capacity could therefore be retired before 2030 .

Various projections to 2030 are available for future coal emissions from China and India. ${ }^{43,44}$ The general consensus is that India emissions will increase while China emissions will decrease, the latter because of emission controls. ${ }^{38,43}$ Emissions in both the U.S. and the European Union are projected to decrease by $\sim 70 \%$ by $2030 .^{45,46}$ These reductions, which assume continued compliance with recent regulations, would result in total coal emissions of $\sim 1.5 \mathrm{Tg} \mathrm{a}^{-1}$ each for $\mathrm{SO}_{2}$ and $\mathrm{NO}_{x}$ in the U.S. and $\sim 1 \mathrm{Tg} \mathrm{a}^{-1}$ each for $\mathrm{SO}_{2}$ and $\mathrm{NO}_{x}$ in Europe. Based on these projections, our results suggest that coal emissions from Southeast Asia in 2030 could exceed the sum of emissions in the U.S. and Europe.

Health Impact Assessment. We follow the methods outlined in Anenberg et al. ${ }^{13}$ (applied more recently by Fang et al. ${ }^{47}$ and Silva et al. ${ }^{48}$ ) to estimate premature mortality in adults (age 30 and older) from coal-related $\mathrm{PM}_{2.5}$ and ozone pollution. We use for this purpose the population distribution for 2010 from the Center for International Earth Science Information Network (CIESIN) (http://beta.sedac.ciesin. columbia.edu/data/collection/gpw-v4), scaled to match the national population totals for 2011 from the 2015 Revision of the United Nations World Population Prospects (http://esa. un.org/unpd/wpp/). The adjusted CIESIN population data are regridded from $0.5^{\circ} \times 0.5^{\circ}$ horizontal resolution to the GEOSChem resolution of $0.5^{\circ} \times 0.666^{\circ}$. Coal-related pollution in 2011 is calculated as the difference between the GEOS-Chem simulation with 2011 emissions for the countries in Table 1 and the simulation with zero coal emissions for these countries.

Premature deaths attributable to a particular risk factor, in this case coal-related $\mathrm{PM}_{2.5}$ and ozone, are those occurring in excess of the baseline death rate (the death rate observed in the absence of the risk factor of interest, in number of deaths per
1000 people per year). Death rates can be calculated for all causes of death ("all-cause") or for individual causes ("causespecific"). We use cause-specific death rates because this approach is thought to incur lower errors when applying concentration response factors (discussed below) based on cohort studies done in the U.S. ${ }^{47}$ We include stroke, ischemic heart disease (IHD), other cardiovascular disease, lung and throat cancer, chronic obstructive pulmonary disease (COPD), lower respiratory infections (LRI), and other respiratory diseases as independent causes of premature death due to $\mathrm{PM}_{2.5}$ pollution. We only include ozone-related deaths related to respiratory diseases. For our 2011 mortality calculations, we use national cause-specific baseline death rates for 2012 from the World Health Organization ${ }^{49}$ (http://www.who.int/ healthinfo/global_burden_disease/en/). Death rates for the 2030 health calculations are discussed in the "Future Health Impact Projections" section below.

Relating a change in pollutant concentration to premature mortality requires concentration response factors, or CRFs, empirically derived from long-term cohort studies. Annual average $\mathrm{PM}_{2.5}$ concentration is the standard metric for assessing health effects from chronic $\mathrm{PM}_{2.5}$ exposure. ${ }^{50,51}$ For ozone, we use the average daily maximum $1 \mathrm{~h}$ ozone concentration during the seasonal 6-month window of peak ozone exposure. ${ }^{52}$

To quantify the burden of disease from coal pollution in each country, we first calculate the population-weighted exposure by multiplying the population distribution from CIESIN with the annual coal-related increases in annual mean $\mathrm{PM}_{2.5}$ or seasonal maximum $1 \mathrm{~h}$ ozone from GEOS-Chem, and dividing by the national population totals. We then take the cause-specific death rates by country and assume the same CRF function shape used in Anenberg et al. ${ }^{13}$ to calculate the change in annual premature mortality $\Delta \mathrm{M}$ [deaths per year] due to coal pollution for each cause of death $\alpha$ in each country k:

$$
\Delta M_{\alpha, \mathrm{k}}=y_{0_{\alpha, \mathrm{k}}}\left(1-\exp ^{-\beta_{\alpha} \Delta x_{\mathrm{k}}}\right) P_{\mathrm{k}}
$$

where $y_{0}$ is the cause-specific baseline death rate (\% per year) in the country, $\Delta x$ is the population-weighted change in pollutant concentration in $\mu \mathrm{g} \mathrm{m}^{-3}$ (for $\mathrm{PM}_{2.5}$ ) or ppb (for ozone), $\beta$ is the cause-specific CRF relating a one-unit change in each pollutant to the predicted change in premature mortality (see SI Table S1 for relative risk (RR) values assumed for each cause of death from the American Cancer Society (ACS) cohort studies; ${ }^{50,52}$ see Anenberg et al. ${ }^{13}$ for the derivation of $\beta$ from $\mathrm{RR}$ ), and $\mathrm{P}$ is the total population of the country. We estimate premature mortality by country rather than by individual model grid cell because the epidemiological data (i.e., death rates) are only available at the national level, as are much of population projection data for 2030 (see Future Health Impact Projections section). The uncertainty ranges reported are derived using low, central, and high estimates for each RR value (SI Table $\mathrm{S} 1$ ). We also tested the sensitivity of our calculations to imposing high (HCT) and low (LCT) $\mathrm{PM}_{2.5}$ concentration thresholds above and below which the relationship between mortality and pollutant concentration becomes less certain. Following Anenberg et al., ${ }^{13}$ we impose a HCT of $50 \mu \mathrm{g} \mathrm{m}^{-3}$ and a LCT of $5.8 \mu \mathrm{g} \mathrm{m}^{-3}$ on the gridded GEOS-Chem $\mathrm{PM}_{2.5}$ results before calculating the national population-weighted $\mathrm{PM}_{2.5}$ averages to estimate mortality. The combined effect of imposing both thresholds on total estimated mortality was less than 7\% (not shown). We do not impose concentration thresholds for ozone. 
Future Health Impact Projections. To estimate changes in premature mortality due to future coal pollution, we follow the approach outlined above but also account for changes between 2011 and 2030 in the population size, geographic distribution, and epidemiological profile. Aside from overall population growth, many countries in Southeast Asia are experiencing rapid urbanization, resulting in higher population densities in polluted areas. The populations are also undergoing changes in age structure and lifestyle (diet, activity level, income, etc.) that may influence vulnerability to disease, resulting in changes in baseline death rates. Before including these factors in our mortality estimates, we first calculate national population-weighted pollution totals for 2030 from the increase in coal pollution from GEOS-Chem, taken as the difference between the 2030 and 2011 simulations, and the geographic population distribution for 2011. These initial 2030 estimates will hereafter be referred to as the "original exposure estimates". The future population projections discussed below are then used to modify the original exposure estimates to reflect the additional influences of population growth, urbanization, and baseline health status changes on pollution exposure and associated mortality in 2030.

For changes in population numbers by 2030 , we use countrylevel projections of population growth for 2030 from the World Bank (http://data.worldbank.org/data-catalog/populationprojection-tables). We multiply the original exposure estimates for each country by the updated population totals for 2030 to include the influence of national population growth on future coal pollution exposure.

We account for the influence of urbanization by including World Bank projections of the fraction of the population living in urban areas in 2030 (http://databank.worldbank.org/data/, "Health Nutrition and Population Statistics: Population estimates and projections" database). These projections are only given at the national level. Following Brauer et al., ${ }^{53}$ we define urban grid cells in 2011 as those in the CIESIN GPWv4 data with population density greater than 600 people per $\mathrm{km}^{2}$. We then use the World Bank projections to scale the urban vs rural fractions of individual countries to estimated 2030 levels.

To estimate the expected changes in baseline cause-specific death rates due to changes in health status characteristics in 2030, we used the central (rather than "pessimistic" or "optimistic") total death rate projections from the Global Burden of Disease (GBD) for 2030 updated with the 2013 Global Health Estimates (http://www.who.int/healthinfo/ global_burden_disease/projections/en/). ${ }^{54}$ The GBD projections for 2030 are not done by country but by various groupings. Here we use the World Bank Income Groups: low income, lower middle income, upper middle income, and high income. Each country is assigned to one of these income groups based on gross national income per capita (http://data. worldbank.org/news/new-country-classifications-2015). We estimate cause-specific baseline death rates for each country in 2030 by scaling the national 2012 specific baseline death rates (described above) based on the relative change of GBD death rate projections between 2012 and 2030 for the relevant income category for each country.

\section{RESULTS AND DISCUSSION}

Figure 2 shows the increases $(\Delta)$ in annual mean surface $\mathrm{PM}_{2.5}$ and 6-month averaged daily maximum $1 \mathrm{~h}$ ozone in 2011 due to coal emissions for the countries of Table 1 (populationweighted changes in $\mathrm{PM}_{2.5}$ and ozone by country are listed in SI
Coal Air Pollution in 2011
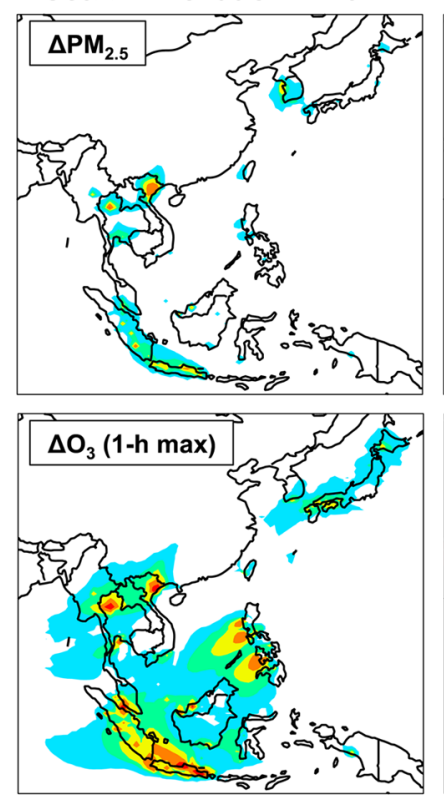

( $\mu \mathrm{g} \mathrm{m}^{-3}$ or $\mathrm{ppb}$ )
Exposure Density in 2011
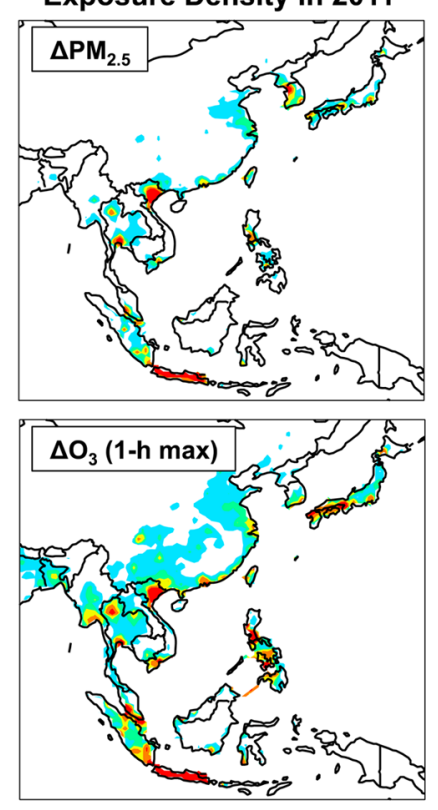

$\left(\mu \mathrm{g} \mathrm{m}^{-3}\right.$ or $\mathrm{ppb} \times 100$ people $\mathrm{km}^{-2}$ )

$$
\begin{array}{lllllll}
\hline 0.10 & 0.20 & 0.50 & 1.00 & 2.00 & 5.00 & 8.00
\end{array}
$$

Figure 2. Simulated increases $(\Delta)$ in surface $\mathrm{PM}_{2.5}\left(\mu \mathrm{g} \mathrm{m}^{-3}\right)$ and ozone (ppb) in Southeast Asia due to coal pollution in 2011, and associated population exposure density (multiplying the concentration increase by the population density). Coal pollution in 2011 is determined by the difference between a simulation with 2011 emissions and a simulation with zero coal emissions for the countries in Table 1 (emissions in other countries are unchanged). Values for $\mathrm{PM}_{2.5}$ are annual means and values for ozone are $1 \mathrm{~h}$ daily maxima averaged for the locally determined 6 month high-ozone season. These metrics are used for the premature mortality calculations as described in the text.

Table S2). We also show the resulting exposure densities, computed by multiplying by population density, in order to illustrate the spatial distribution of pollution exposure across the region prior to the country-specific health impact assessment. Corresponding figures showing increases from coal emissions in individual countries are in the SI (Figures S1-S2). Our $\mathrm{PM}_{2.5}$ calculations assume dry conditions and do not include condensed water, resulting in conservative $\mathrm{PM}_{2.5}$ mass estimates (e.g., assuming $35 \%$ relative humidity increases inorganic $\mathrm{PM}_{2.5}$ mass by $\sim 33 \%$ compared to dry conditions). $\mathrm{PM}_{2.5}$ increases are localized over major urban areas and reach $3 \mu \mathrm{g} \mathrm{m}^{-3}$ over northern Vietnam. Ozone increases are more spread out but again show peaks of $2-5$ ppb over urban areas. These urban influences are magnified in the population exposure density panels, which also show large impacts on eastern China caused by transboundary transport of pollution from Southeast Asia. We discuss the influence on China in more detail below. While, as we show, the contribution of Southeast Asian coal plant emissions to regional $\mathrm{PM}_{2.5}$ and ozone air quality is significant, total PM and ozone concentrations in East and Southeast Asia are also heavily influenced by noncoal emission sources such as fires and biofuels. ${ }^{55}$ Since we do not examine these other sectors in our analysis, a direct comparison between observed and modeled $\mathrm{PM}$ and ozone concentrations would have limited utility for evaluating the coal-related pollutant changes simulated here. Isolating changes in observed PM and ozone due to Southeast 
Asian coal plant emissions would be informative, but also extremely difficult given the limited coverage of surface monitoring sites in this region.

Figure 3 shows the same results for 2030. Increases in $\mathrm{PM}_{2.5}$ exceed $11 \mu \mathrm{g} \mathrm{m}^{-3}$ over Hanoi and reach $5 \mu \mathrm{g} \mathrm{m}^{-3}$ over Jakarta

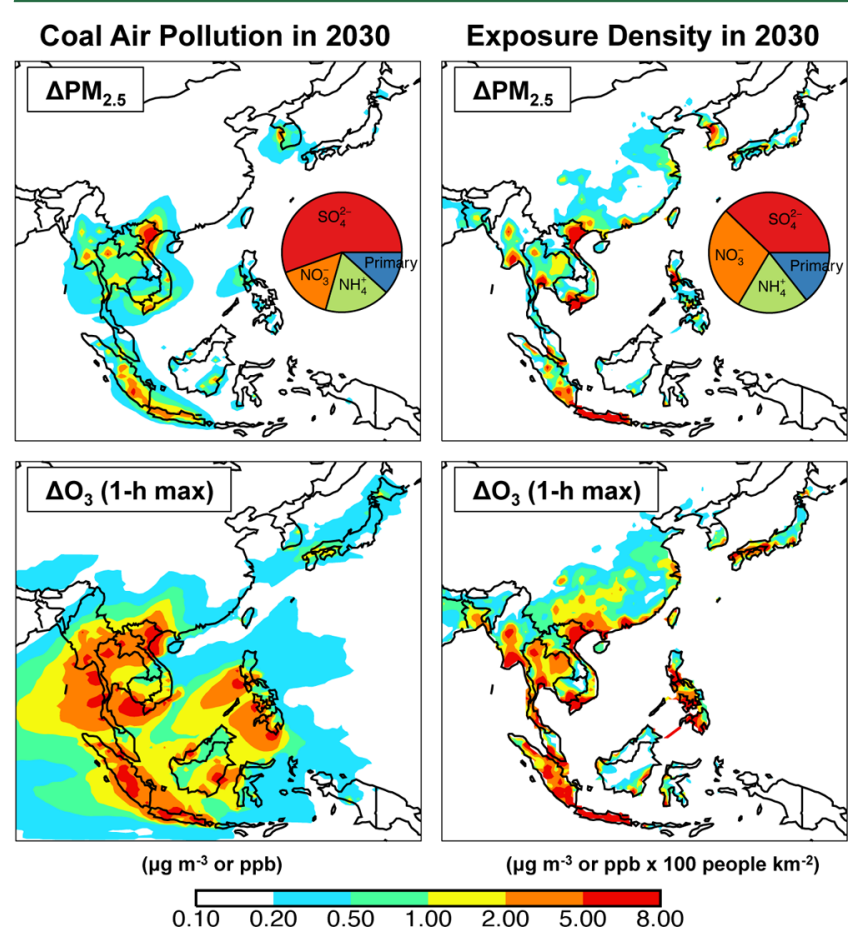

Figure 3. Same as Figure 2 but for 2030. Pie charts inset show relative contributions of different aerosol types to regional $\mathrm{PM}_{2.5}$ coal pollution.

and much of southern Sumatra. Increases in ozone are as high as $15 \mathrm{ppb}$ over Indonesia and northern Vietnam. Sulfate contributes $56 \%$ of the overall regional increase in $\mathrm{PM}_{2.5}$, followed by ammonium (18\%), nitrate (15\%), and primary particulate emission (11\%). From an exposure perspective, sulfate is somewhat less important (38\%) while nitrate is more important (29\%) due to abundant ammonia from croplands near populated areas, particularly surrounding Hanoi and Ho Chi Minh City in Vietnam and across much of Sumatra and Java in Indonesia.

The population-weighted $\mathrm{PM}_{25}$ and ozone increases in Figures 2 and 3, combined with eq 3, allow us to compute the current and future premature deaths caused by coal emissions. We estimate 19880 (11400-28 400) premature deaths in 2011 from coal combustion in the countries of Table 1, where the numbers in parentheses indicate the uncertainty bounds of the estimates derived from the high and low RR values shown in SI Table S1. Of these 17940 are due to $\mathrm{PM}_{2.5}$ and 1940 due to ozone. For comparison, we also estimate premature mortality for 2011 using values from Burnett et al. ${ }^{56}$ (SI Table S3). We do not evaluate the 2030 results following the Burnett et al. ${ }^{56}$ approach because in this work we do not project emissions for other sectors or countries outside of Table 1 to 2030, and the Burnett et al. ${ }^{56}$ relationships are more sensitive to baseline pollutant concentrations than the ACS functions. Figure 4 shows the breakdown by country and by cause of death (the breakdown shown is for 2030, but percentages for 2011 are almost identical). Most premature deaths are due to ischemic heart disease (6470) and stroke (5970). Mortality is highest in Indonesia (7480 excess deaths per year) followed by Vietnam (4250 excess deaths per year). China incurs the third highest mortality after Indonesia and Vietnam with 3150 excess deaths per year. All excess deaths estimated for China are due to transboundary pollution.

By 2030, we project that total regional premature mortality due to coal pollution will be 63520 excess deaths from $\mathrm{PM}_{2.5}$ and 6140 from ozone, resulting in a total of 69660 (40 080126710 ) excess deaths per year (Figure 4; see SI Figure S4 for the relative contributions of projected population growth, urbanization, and baseline health status changes to these estimates). The highest mortality totals again occur in Indonesia (24 400 excess deaths per year), Vietnam (19220 excess deaths per year), and China (8870 excess deaths per year). Myanmar experiences the fourth-highest mortality in 2030 with 4030 excess deaths per year, reflecting the dramatic increase in emissions projected there (Table 1).

The right panel of Figure 4 shows for each country the contributions to 2030 premature mortality from domestic and foreign coal emissions. These were obtained from the national simulation results with vs without coal emissions for individual countries. We find that more than $80 \%$ of coal-related mortality in individual countries of Southeast Asia is due to domestic emissions. The exception is Thailand, for which transboundary pollution from nearby Vietnam is larger than the domestic source.

Vietnam is the largest transboundary contributor to 2030 mortality in China, mainly influencing southern China by direct transport of coal $\mathrm{PM}_{2.5}$. In addition, we see in the right-hand panel of Figure 3 significant population exposure in the densely populated East China Plain. The increase in $\mathrm{PM}_{2.5}$ there is mostly driven by $\mathrm{PM}_{2.5}$ pollution transported from South Korea (SI Figure S1) and by the increase in ozone, speeding up the rate at which local Chinese $\mathrm{SO}_{2}$ and $\mathrm{NO}_{x}$ emissions are converted to sulfate and nitrate.

Leibensperger et al. ${ }^{57}$ previously showed that $\mathrm{NO}_{x}$ emissions in the US, Europe, and China cause intercontinental $\mathrm{PM}_{2.5}$ pollution by increasing surface ozone on a hemispheric scale, leading to faster $\mathrm{PM}_{2.5}$ production in downwind continents from the oxidation of locally emitted $\mathrm{SO}_{2}$ and $\mathrm{NO}_{x}$, that is, the same effect that we find here on a smaller scale for the East China Plain (Figure 3). We used the global GEOS-Chem simulation to examine the influence of Southeast Asian coal emissions on other continents but found the effects to be very small. Maximum annual average intercontinental $\mathrm{PM}_{2.5}$ enhancements occur over polluted northern Europe but are less than $0.01 \mu \mathrm{g} \mathrm{m}^{-3}$. Peak intercontinental increases in seasonal average daily maximum $1 \mathrm{~h}$ surface ozone occur over other tropical continents but are less than $0.5 \mathrm{ppb}$. Even when normalized to the magnitude of $\mathrm{NO}_{x}$ emissions, intercontinental influence from Southeast Asia on surface $\mathrm{PM}_{2.5}$ in the U.S. and Europe is small compared to that from northern midlatitude continents ${ }^{57,58}$ because Southeast Asia is out of the westerly midlatitude circulation. On the other hand, seasonal southerly flow from Southeast Asia leads to stronger influence on China as shown in Figure 3. Intercontinental influence from Southeast Asia on surface pollution in other tropical continents is weak in part because of strong vertical mixing, limiting influence on ozone, and relatively low emissions of $\mathrm{SO}_{2}$ and $\mathrm{NO}_{x}$ in these other continents, limiting oxidant-mediated influence on $\mathrm{PM}_{2.5}$. 


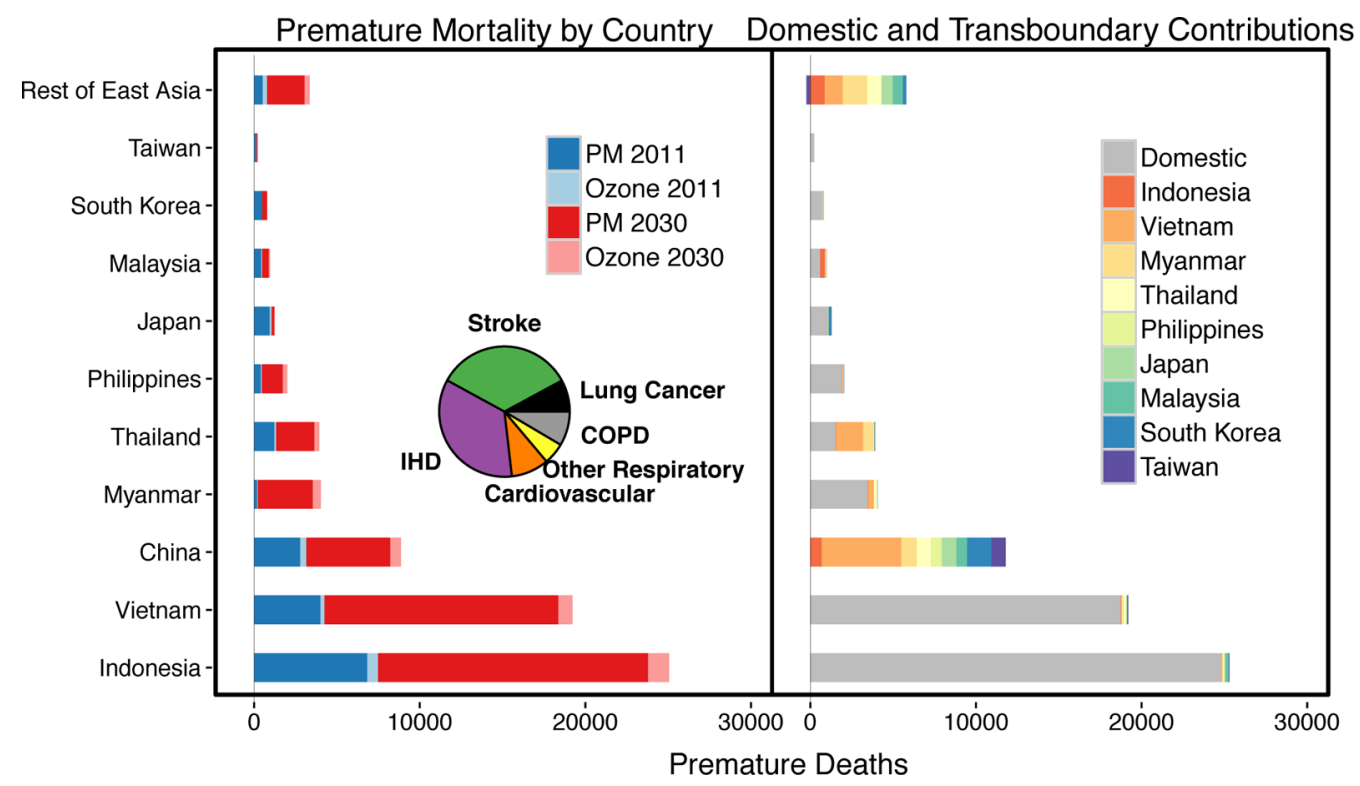

Figure 4. Coal-related mortality due to emissions in Southeast Asia (countries in Table 1). The left panel shows the premature deaths in individual countries. Premature deaths due to 2011 emissions are shown in blue, and increases between 2011 and projected 2030 emissions are shown in red (population-normalized results are shown in Table S4). Deaths due to $\mathrm{PM}_{2.5}$ and ozone are shown separately. The fraction of $\mathrm{PM}_{2.5}$-related mortality by cause is shown in the pie chart as an average for the whole region in 2030 (IHD $\equiv$ ischemic heart disease, COPD $\equiv$ chronic obstructive pulmonary disease). All ozone-related mortality is from respiratory diseases. The right panel shows the 2030 coal-related mortality in each country broken down by contributions from domestic and transboundary sources (see SI Figure S5 for the domestic and transboundary contributions in 2011). Source countries responsible for transboundary pollution are identified in the legend. As computed here, mortality in China and Rest of East Asia (not included in Table 1) is solely from transboundary pollution. The mortality totals in the right panel are the sums of the contributions from the national simulations with vs without coal emissions for the individual countries in Table 1; because of chemical and CRF nonlinearities they may be greater than the mortality totals in the left panels.

There are several limitations to our analysis. First, our analysis only includes one year of meteorology and therefore does not account for interannual variability in meteorological parameters (e.g., precipitation or temperature) that may affect pollutant formation and transport. We also do not account for future changes in climate, which may influence $\mathrm{PM}_{2.5}$ and ozone formation over Asia. ${ }^{47}$ Second, we do not account for potential changes in total PM and ozone concentrations by 2030 due to noncoal plant emissions (e.g., biofuels or residential coal) or future emissions in countries outside Table 1. Because we use a nonlinear CRF function, assuming different background PM and ozone concentrations for 2030 might lead to different estimates for premature mortality due to coal-related pollution, especially in areas with lower background PM and ozone. Also, our total mortality estimates assume that the $\mathrm{PM}_{2.5^{-}}$and ozone-related deaths can be added together, which could lead to double counting if the observed influences of $\mathrm{PM}_{2.5}$ and ozone on premature mortality are not independent of each other. However, single pollutant assessments may also underestimate the total disease burden by neglecting the effects of other pollutants that may be present. ${ }^{59}$ Ultimately our results are not significantly sensitive to this assumption since ozone-related mortality represents less than $10 \%$ of our total estimate; including only $\mathrm{PM}_{2.5}$-related mortality still produces an estimate of 64000 excess deaths annually from Southeast Asian coal pollution by 2030. Lastly, although comparisons vary by cause of death and by country, our total premature mortality estimates are also almost twice as high overall for 2011 compared to estimates produced with the Burnett et al. ${ }^{56}$ relationship, suggesting that the CRFs we use may be biased high compared to other approaches. On the other hand, the $\mathrm{PM}_{2.5}$ estimates we report were calculated assuming dry conditions, possibly underestimating $\mathrm{PM}_{2.5}$ by as much as $30 \%$ and offsetting some of the potential overestimate incurred by our choice of CRFs. Additionally, while our total mortality estimates for 2011 are high compared to using the values from Burnett et al., ${ }^{56}$ our estimate for premature mortality in Indonesia, the country with the most excess deaths overall, is lower by $20 \%$.

In contrast to the global trend toward cleaner fuel, the future of power generation in Southeast Asia is currently projected to rely on coal. ${ }^{9}$ Our analysis shows that the cost to human health of this coal-dominated energy trajectory is severe. We estimate $\sim 20000$ premature deaths every year due to coal pollution from currently operating power plants in Southeast Asia, with the largest effects in Indonesia and Vietnam. These numbers may increase to $\sim 70000$ excess deaths per year by 2030 if all currently approved coal plants in Southeast Asia become operational. Beyond Indonesia and Vietnam, the third greatest mortality toll from Southeast Asian coal emissions is in China, where we expect $\sim 9000$ premature deaths annually by 2030 . Coal emissions from power plants in China are presently declining, ${ }^{2,60}$ so that rising transboundary pollution influence from Southeast Asia will likely become of increasing concern if no action is taken to avoid emission increases from that region.

In January 2016, the Vietnam government announced plans to drastically reduce their plans for future coal expansion ${ }^{61}$ citing both climate and air quality concerns. The air quality concerns drew from preliminary accounts of our work presented at news conferences. ${ }^{62}$ Recognition of the public health costs of a coal-based future may guide other countries in Southeast Asia to follow Vietnam's lead and choose a more sustainable pathway for meeting their energy needs. 


\section{ASSOCIATED CONTENT}

\section{S Supporting Information}

The Supporting Information is available free of charge on the ACS Publications website at DOI: 10.1021/acs.est.6b03731.

Additional information about relative risk factors used, projected increases in coal pollution by 2030 from the national simulations, power plant locations in 2011 and 2030, contributions of population projections to 2030 mortality estimates in each country, and domestic and transboundary contributions to pollution in 2011, along with full coal emissions data set and information used to produce the emission estimates (PDF) (XLSX)

\section{AUTHOR INFORMATION}

\section{Corresponding Author}

*Phone: 617496 9428; e-mail: skoplitz@fas.harvard.edu.

\section{ORCID ${ }^{\circ}$}

Shannon N. Koplitz: 0000-0003-1745-903X

Notes

The authors declare no competing financial interest.

\section{ACKNOWLEDGMENTS}

This work was supported by the Growald Family Foundation. Colleen Reid's work was supported through the Robert Wood Johnson Foundation Health \& Society Scholars program.

\section{REFERENCES}

(1) Amann, M.; Klimont, Z.; Wagner, F. Regional and Global Emissions of Air Pollutants: Recent Trends and Future Scenarios. Annu. Rev. Environ. Resour. 2013, 38 (1), 31-55.

(2) Klimont, Z.; Smith, S. J.; Cofala, J. The last decade of global anthropogenic sulfur dioxide: 2000-2011 emissions. Environ. Res. Lett. 2013, 8 (1), 014003.

(3) Chen, W.; Xu, R. Clean coal technology development in China. Energy Policy 2010, 38 (5), 2123-2130.

(4) Wang, S.; Streets, D. G.; Zhang, Q.; He, K.; Chen, D.; Kang, S.; $\mathrm{Lu}, \mathrm{Z}$.; Wang, Y. Satellite detection and model verification of NOx emissions from power plants in Northern China. Environ. Res. Lett. 2010, 5 (4), 044007.

(5) Lu, Z.; Streets, D. G.; de Foy, B.; Krotkov, N. A. Ozone Monitoring Instrument Observations of Interannual Increases in $\mathrm{SO} 2$ Emissions from Indian Coal-Fired Power Plants during 2005-2012. Environ. Sci. Technol. 2013, 47 (24), 13993-14000.

(6) Guttikunda, S. K.; Jawahar, P. Atmospheric emissions and pollution from the coal-fired thermal power plants in India. Atmos. Environ. 2014, 92, 449-460.

(7) Southeast Asia Energy Outlook: World Energy Outlook Special Report; International Energy Agency: Paris, France, 2013; https:// www.iea.org/publications/freepublications/publication/ SoutheastAsiaEnergyOutlook WEO2013SpecialReport.pdf.

(8) McDonald, P. A Population Projection for Indonesia, 20102035. Bull. Indones. Econ. Stud. 2014, 50 (1), 123-129.

(9) Southeast Asia Energy Outlook 2015: World Energy Outlook Special Report; International Energy Agency: Paris, France, 2015; https:// www.iea.org/publications/freepublications/publication/weo2015 southeastasia.pdf.

(10) Zhu, W. Coal to Surpass Gas in Southeast Asia Power Boom, IEA Say. Bloomberg Business. October 2, 2013. http://www.bloomberg. $\mathrm{com} /$ news/articles/2013-10-02/coal-to-surpass-gas-in-southeast-asiapower-use-boom-iea-says.

(11) Forouzanfar, M. H.; et al. Global, regional, and national comparative risk assessment of 79 behavioral, environmental and occupational, and metabolic risks or clusters of risks, 1990-2015: a systematic analysis for the Global Burden of Disease Study 2015. Lancet 2016, 388 (10053), 1659-1724.

(12) Ainsworth, E. A. Rice production in a changing climate: a metaanalysis of responses to elevated carbon dioxide and elevated ozone concentration. Glob. Change Biol. 2008, 14 (7), 1642-1650.

(13) Anenberg, S. C.; Horowitz, L. W.; Tong, D. Q.; West, J. J. An estimate of the global burden of anthropogenic ozone and fine particulate matter on premature human mortality using atmospheric modeling. Environ. Health Perspect. 2010, 118 (9), 1189.

(14) Miller, M. J. Retrofit SO2 and NOx control technologies for coal-fired power plants. Environ. Prog. 1986, 5 (3), 171-177.

(15) Zhao, Y.; Wang, S.; Nielsen, C. P.; Li, X.; Hao, J. Establishment of a database of emission factors for atmospheric pollutants from Chinese coal-fired power plants. Atmos. Environ. 2010, 44 (12), 15151523.

(16) Park, R. J.; Jacob, D. J.; Field, B. D.; Yantosca, R. M.; Chin, M. Natural and transboundary pollution influences on sulfate-nitrateammonium aerosols in the United States: Implications for policy. J. Geophys. Res. 2004, 109 (D15). DOI: 10.1029/2003JD004473.

(17) Kim, P. S.; Jacob, D. J.; Fisher, J. A.; Travis, K.; Yu, K.; Zhu, L.; Yantosca, R. M.; Sulprizio, M. P.; Jimenez, J. L.; Campuzano-Jost, P.; et al. Sources, seasonality, and trends of southeast US aerosol: an integrated analysis of surface, aircraft, and satellite observations with the GEOS-Chem chemical transport model. Atmos. Chem. Phys. 2015, 15 (18), 10411-10433.

(18) Chen, D.; Wang, Y.; McElroy, M. B.; He, K.; Yantosca, R. M.; Le Sager, P. Regional CO pollution and export in China simulated by the high-resolution nested-grid GEOS-Chem model. Atmos. Chem. Phys. 2009, 9 (11), 3825-3839.

(19) Wang, Y.; Zhang, Q. Q.; He, K.; Zhang, Q.; Chai, L. Sulfatenitrate-ammonium aerosols over China: response to 2000-2015 emission changes of sulfur dioxide, nitrogen oxides, and ammonia. Atmos. Chem. Phys. 2013, 13 (5), 2635-2652.

(20) Van Donkelaar, A.; Martin, R. V.; Leaitch, W. R.; Macdonald, A. M.; Walker, T. W.; Streets, D. G.; Zhang, Q.; Dunlea, E. J.; Jimenez, J. L.; Dibb, J. E.; et al. Analysis of aircraft and satellite measurements from the Intercontinental Chemical Transport Experiment (INTEXB) to quantify long-range transport of East Asian sulfur to Canada. Atmos. Chem. Phys. 2008, 8 (11), 2999-3014.

(21) Fairlie, T. D.; Jacob, D. J.; Dibb, J. E.; Alexander, B. Impact of mineral dust on nitrate, sulfate, and ozone in transpacific Asian pollution plumes. Atmos. Chem. Phys. 2010, 10 (8), 3999-4012.

(22) Fu, T. M.; Cao, J. J.; Zhang, X. Y.; Lee, S. C.; Zhang, Q.; Han, Y. M.; Qu, W. J.; Han, Z.; Zhang, R.; Wang, Y. X.; et al. Carbonaceous aerosols in China: top-down constraints on primary sources and estimation of secondary contribution. Atmos. Chem. Phys. 2012, 12 (5), $2725-2746$.

(23) Xu, X.; Wang, J.; Henze, D. K.; Qu, W.; Kopacz, M. Constraints on aerosol sources using GEOS-Chem adjoint and MODIS radiances, and evaluation with multisensor (OMI, MISR) data. J. Geophys. Res. Atmos. 2013, 118 (12), 6396-6413.

(24) Zhang, L.; Jacob, D. J.; Boersma, K. F.; Jaffe, D. A.; Olson, J. R.; Bowman, K. W.; Worden, J. R.; Thompson, A. M.; Avery, M. A.; Cohen, R. C.; et al. Transpacific transport of ozone pollution and the effect of recent Asian emission increases on air quality in North America: an integrated analysis using satellite, aircraft, ozonesonde, and surface observations. Atmos. Chem. Phys. 2008, 8 (20), 61176136.

(25) Wang, Y.; Hao, J.; McElroy, M. B.; Munger, J. W.; Ma, H.; Chen, D.; Nielsen, C. P. Ozone air quality during the 2008 Beijing Olympics: effectiveness of emission restrictions. Atmos. Chem. Phys. 2009, 9 (14), 5237-5251.

(26) Worden, J.; Jones, D. B. A.; Liu, J.; Parrington, M.; Bowman, K.; Stajner, I.; Beer, R.; Jiang, J.; Thouret, V.; Kulawik, S.; et al. Observed vertical distribution of tropospheric ozone during the Asian summertime monsoon. J. Geophys. Res. 2009, 114 (D13). DOI: 10.1029/2008JD010560. 
(27) Wang, Y.; Zhang, Y.; Hao, J.; Luo, M. Seasonal and spatial variability of surface ozone over China: contributions from background and domestic pollution. Atmos. Chem. Phys. 2011, 11 (7), 3511-3525.

(28) Trivitayanurak, W.; Palmer, P. I.; Barkley, M. P.; Robinson, N. H.; Coe, H.; Oram, D. E. The composition and variability of atmospheric aerosol over Southeast Asia during 2008. Atmos. Chem. Phys. 2012, 12 (2), 1083-1100.

(29) Kim, P. S.; Jacob, D. J.; Mickley, L. J.; Koplitz, S. N.; Marlier, M. E.; DeFries, R. S.; Myers, S. S.; Chew, B. N.; Mao, Y. H. Sensitivity of population smoke exposure to fire locations in Equatorial Asia. Atmos. Environ. 2015, 102, 11-17.

(30) Platts. World Electric Power Plants Database; http://www. platts.com/products/world-electric-power-plants-database (accessed December 2014).

(31) Wheeler, D.; Ummel, K. Calculating CARMA: global estimation of $\mathrm{CO} 2$ emissions from the power sector. Center for Global Development 2008. Available at http://www.cgdev.org/publication/ calculating-carma-global-estimation-co2-emissions-power-sectorworking-paper-145.10.2139/ssrn.1138690

(32) Massachusetts Institute of Technology: The future of coal: options in a carbon-constrained world. Massachusetts Institute of Technology 2007. Available at http://web.mit.edu/coal.

(33) Air Pollution from Electricity-Generating Large Combustion Plants: An Assessment of the Theoretical Emission Reduction of $\mathrm{SO}_{2}$ and $\mathrm{NO}_{x}$ through Implementation of BAT as set in the BREFs; European Environmental Agency, Copenhagen, Denmark, 2008; No 4/2008, ISSN 0013-936X; http://www.eea.europa.eu/publications/technical_ report 20084.

(34) Kurokawa, J.; Ohara, T.; Morikawa, T. Emissions of air pollutants and greenhouse gases over Asian regions during 20002008: Regional Emission inventory in ASia (REAS) version 2. Atmos. Chem. Phys. 2013, 13 (21), 11019-11058.

(35) Emissions Factors \& AP-42, Compilation of Air Pollutant Emission Factors; United States Environmental Protection Agency, 1995; https://www3.epa.gov/ttn/chief/ap42.

(36) Shearer, C.; Ghio, N.; Myllyvirta, L.; Nace, T. Boom and Bust; CoalSwarm and the Sierra Club, 2015; http://endcoal.org/wpcontent/uploads/2015/05/BoomBustMarch16embargoV8.pdf.

(37) Proops, J.; Gay, P. W.; Speck, S.; Schröder, T. The lifetime pollution implications of various types of electricity generation. An input-output analysis. Energy Policy 1996, 24 (3), 229-237.

(38) Liu, F.; Zhang, Q.; Tong, D.; Zheng, B.; Li, M.; Huo, H.; He, K. $B$. High-resolution inventory of technologies, activities, and emissions of coal-fired power plants in China from 1990 to 2010. Atmos. Chem. Phys. 2015, 15 (23), 13299-13317.

(39) Lu, Z.; Zhang, Q.; Streets, D. G. Sulfur dioxide and primary carbonaceous aerosol emissions in China and India, 1996-2010. Atmos. Chem. Phys. 2011, 11 (18), 9839-9864.

(40) Lu, Z.; Streets, D. G. Increase in $\mathrm{NO}_{x}$ Emissions from Indian Thermal Power Plants during 1996-2010: Unit-Based Inventories and Multisatellite Observations. Environ. Sci. Technol. 2012, 46 (14), 7463-7470.

(41) Electric Power Annual 2010; U.S. Energy Information Administration, Washington, DC, 2011; http://www.eia.gov/ electricity/annual/archive/03482010.pdf.

(42) Platts. World Electric Power Plants Database. Website: http:// www.platts.com/products/world-electric-power-plants-database, accessed December 2015.

(43) Zhao, Y.; Zhang, J.; Nielsen, C. P. The effects of energy paths and emission controls and standards on future trends in China's emissions of primary air pollutants. Atmos. Chem. Phys. 2014, 14 (17), $8849-8868$

(44) Cofala, J.; Bertok, I.; Borken-Kleefeld, J.; Heyes, C.; Kiesewetter, G.; Klimont, Z.; Purohit, P.; Rafaj, P.; Sander, R.; Schöpp, W.; Amann, M. Implications of energy trajectories from the World Energy Outlook 2015 for India's air pollution. International Institute for Applied Systems Analysis: Laxenburg, Austria,(submitted to International Energy Agency: Paris, France) 2015; http://www.
worldenergyoutlook.org/media/weowebsite/2015/Air pollution emissions_impacts_India_WEO2015_IIASA.pdf.

(45) Regulatory Impact Analysis for the Proposed Carbon Pollution Guidelines for Existing Power Plants and Emission Standards for Modified and Reconstructed Power Plants; United States Environmental Protection Agency: Research Triangle Park, NC, 2014, EPA-452/R14-002; https://www.epa.gov/sites/production/files/2014-06/ documents/20140602ria-clean-power-plan.pdf.

(46) Future Emissions of Air Pollutants in Europe-Current Legislation Baseline and the Scope for Further Reductions: Service Contract on Monitoring and Assessment of Sectorial Implementation Actions, TSAP Report; Amann, M., Ed.; International Institute for Applied Systems Analysis: Laxenburg, Austria, 2012; http://ec.europa.eu/environment/ air/pdf/TSAP-BASELINE-20120613[1].pdf.

(47) Fang, Y.; Mauzerall, D. L.; Liu, J.; Fiore, A. M.; Horowitz, L. W. Impacts of 21 st century climatic change on global air pollution-related premature mortality. Clim. Change 2013, 121 (2), 239-253.

(48) Silva, R. A.; West, J. J.; Zhang, Y.; Anenberg, S. C.; Lamarque, J. F.; et al. Global premature mortality due to anthropogenic outdoor air pollution and the contribution of past climate change. Environ. Res. Lett. 2013, 8 (3), 034005.

(49) Anenberg, S. C.; Schwartz, J.; Shindell, D.; Amann, M.; Faluvegi, G.; Klimont, Z.; Janssens-Maenhout, G.; Pozzoli, L.; Van Dingenen, R; Vignati, E.; et al. Global air quality and health co-benefits of mitigating near-term climate change through methane and black carbon emission controls. Environ. Health Perspect. 2012, 120 (6), 831-839.

(50) Krewski, D.; Jerrett, M.; Burnett, R. T.; Ma, R.; Hughes, E.; et al. Extended follow-up and spatial analysis of the American Cancer Society study linking particulate air pollution and mortality. Health Effects Institute 2009; http://pubs.healtheffects.org/view.php?id=315.

(51) Quantitative Health Risk Assessment for Particulate Matter; United States Environmental Protection Agency, Office of Air Quality Planning and Standards: Research Triangle Park, NC, 2010; https:// www3.epa.gov/ttn/naaqs/standards/pm/data/PM_RA_FINAL_ June 2010.pdf.

(52) Jerrett, M.; Burnett, R. T.; Pope, C. A., III; Ito, K.; Thurston, G.; Krewski, D.; Shi, Y.; Calle, E.; Thun, M. Long-term ozone exposure and mortality. N. Engl. J. Med. 2009, 360 (11), 1085-1095.

(53) Brauer, M.; Amann, M.; Burnett, R. T.; Cohen, A.; Dentener, F.; Ezzati, M.; Henderson, S. B.; Krzyzanowski, M.; Martin, R. V.; Van Dingenen, R; et al. Exposure assessment for estimation of the global burden of disease attributable to outdoor air pollution. Environ. Sci. Technol. 2012, 46 (2), 652-660.

(54) Mathers, C. D.; Loncar, D. Projections of global mortality and burden of disease from 2002 to 2030. PLOS Med. 2006, 3 (11), e442.

(55) Lelieveld, J.; Evans, J. S.; Fnais, M.; Giannadaki, D.; Pozzer, A. The contribution of outdoor air pollution sources to premature mortality on a global scale. Nature 2015, 525 (7569), 367-371.

(56) Burnett, R. T.; et al. An integrated risk function for estimating the Global Burden of Disease attributable to ambient fine particulate matter exposure. Environ. Health Perspect. 2014, 122, 397-403.

(57) Leibensperger, E. M.; Mickley, L. J.; Jacob, D. J.; Barrett, S. R. H. Intercontinental influence of $\mathrm{NOx}$ and $\mathrm{CO}$ emissions on particulate matter air quality. Atmos. Environ. 2011, 45 (19), 3318-3324.

(58) Fiore, A. M.; Dentener, F. J.; Wild, O.; Cuvelier, C.; Schultz, M. G.; Hess, P.; Textor, C.; Schulz, M.; Doherty, R. M.; Horowitz, L. W.; et al. Multimodel estimates of intercontinental source-receptor relationships for ozone pollution. J. Geophys. Res. 2009, 114 (D4). DOI: $10.1029 / 2008 J D 010816$.

(59) Health Risks of Air Pollution in Europe - HRAPIE Project: Recommendations for Concentration-Response Functions for Cost-Benefit Analysis of Particulate Matter, Ozone and Nitrogen Dioxide; World Health Organization, Regional Office for Europe: Copenhagen, Denmark, 2013; http://www.euro.who.int/en/health-topics/ environment-and-health/air-quality/publications/2013/health-risksof-air-pollution-in-europe-hrapie-project.-recommendations-forconcentrationresponse-functions-for-costbenefit-analysis-ofparticulate-matter,-ozone-and-nitrogen-dioxide. 
(60) Shuo, L. Comment: China's Energy Transition Is Happening Even Faster than You Think; Energy Desk Greenpeace. July 2, 2015; http:// energydesk.greenpeace.org/2015/07/02/comment-chinas-energytransition-is-happening-even-faster-than-you-think/.

(61) King, E. Vietnam to phase out coal, invest in gas and renewables: www.climatechangenews.com. January 25, 2016; http://www. climatechangenews.com/2016/01/25/vietnam-phase-coal-invest-gasrenewables/.

(62) Greenpeace. Coal expansion in Vietnam could claim 25,000 lives per year, press release 2015; http://www.greenpeace.org/seasia/ Press-Centre/Press-Releases/Coal-expansion-in-Vietnam-could-claim25000-lives-per-year/. 